Western Washington University Western CEDAR

\title{
Travel and Insight on the Limen: A Content Analysis of Adventure Travel Narratives
}

Jasmine M. Goodnow

Western Washington University, jasmine.goodnow@wwu.edu

Samit Bordoloi

Western Washington University, samit.bordoloi@wwu.edu

Follow this and additional works at: https://cedar.wwu.edu/healthandhumandev_facpubs

Part of the Health and Physical Education Commons

\section{Recommended Citation}

Goodnow, Jasmine M. and Bordoloi, Samit, "Travel and Insight on the Limen: A Content Analysis of Adventure Travel Narratives" (2017). Health and Human Development. 1.

https://cedar.wwu.edu/healthandhumandev_facpubs/1

This Article is brought to you for free and open access by the Social and Behavioral Sciences at Western CEDAR. It has been accepted for inclusion in Health and Human Development by an authorized administrator of Western CEDAR. For more information, please contact westerncedar@wwu.edu. 


\title{
TRAVEL AND INSIGHT ON THE LIMEN: A CONTENT ANALYSIS OF ADVENTURE TRAVEL NARRATIVES
}

\author{
JASMINE M. GOODNOW* AND SAMIT BORDOLOI $\dagger$ \\ *Department of Health and Human Development, Western Washington University, Bellingham, WA, USA \\ †Woodring College of Education, Western Washington University, Bellingham, WA, USA
}

\begin{abstract}
Travel narratives, both historical and modern, depict a hero's quest for insight and self-discovery where the outward journey is a literal and metaphorical search for one's authentic self, spirituality, and life's meaning. This article reports the results of a study that examined the association between travel's liminal experience and insight. Using content analysis of 50 published adventure travel narratives, a significant association between insight and liminality was identified, and the tentative conclusion that liminal experience may be a stimulus for insight was made. Variables (solo/group travel, travel motivation, gender, and cultural novelty) hypothesized to moderate the association between liminality and insight were also explored. Hierarchical log linear modeling identified only one significant three-way association: travel motive. Travelers who sought to escape negative associations with home were less likely to experience liminality and insight than those who were motivated to travel for other reasons.
\end{abstract}

\section{Key words: Liminality; Insight; Travel narrative; Content analysis}

\section{Introduction}

For many, travel is more than a vacation; it is an inward journey - a quest for insight (Cousineau, 1998; Goodnow \& Ruddell, 2009; Moir-Bussy, 2003) that results in a powerful transformative experience (Reisinger, 2013; Ross, 2010). Many travelers have felt the stirrings that something is missing or wrong with their current life. So they packed their bags, closed the door on their old life, and took their first courageous steps into life "on the road," resolute with hopes of gaining insight into their lives and selves. Reisinger (2013) suggested that:

those who undertake travel engage in an actual physical movement (through time and space) as well as inner psychological development. ... As a result, undertaking an actual trip (physical journey) is often seen as an expression of an inner psychological journey. (p. 27)

Those travelers return home wiser and better able to face the challenges of life (Reisinger, 2013).

Address correspondence to Jasmine Goodnow, Assistant Professor of Recreation/Tourism, Department of Health and Human Development, Western Washington University, Bond Hall 418C, MS 9067, 516 High Street, Bellingham, WA 98225, USA. Tel: +1-540-352-2367;

E-mail: Jasmine.goodnow@wwu.edu 
Adventure travel narratives, the books found in the travel section of book stores, depict stories of travelers being forever "changed" as insights are realized (Campbell, 1968; Goodnow \& Ruddell, 2009; McAvoy \& Dustin, 1989). From a research perspective, adventure travel narratives may hold a key to understanding why travel seems to foster insight and transformation.

As early as the 10th century, travel narratives have been influencing culture and inspiring people to embark on journeys of their own. Although there are millions of travelers every year, only a select few have the motivation and capability to write and publish travel narratives that inspire people to follow their path. Travel narratives inspire some readers to re-create the author's travel itinerary (Goodnow \& Ruddell, 2009; Laing \& Crouch, 2011). Travel can be a valuable avenue for self-discovery because liminality may occur when travelers leave the security, familiarity, and predictability of home and are more open to new and novel ideas (Bloom \& Goodnow, 2013; Goodnow \& Ruddell, 2009).

Liminality comes from the Latin word limen, meaning “a threshold” (Russell, 2005). Turner (1966) described liminality as a transition and "a time and place of withdrawal from normal modes of social action" (p. 167), which is composed of three phases: separation, margin (limen), and aggregation. Adler (1985) suggested that traveling serves as a ritual aid in accomplishing separation (the first phase of liminality) from home and family. Some travelers are motivated to separate themselves from ordinary life and seek a liminal experience in which they may find answers to life's important questions and gain new personal insights (Bloom \& Goodnow, 2013; Noy, 2004; Reisinger, 2013; Shaffer, 2004). Research suggested that travel provides a novel experience that is conducive to new ways of thinking and deeper understanding (Reisinger, 2013; Walle, 1997), and that novelty can free people from the constraints of daily routines and offer freedom and escape from the ordinary (Gilbert \& Abdullah, 2004; Reisinger, 2013). However, the extent to which travel narratives depict instances where liminality is a precondition or facilitator to insight is not clear (Levitt et al., 2004) and warrants further examination. This article explored if liminality experienced through travel may be a means to gaining insight about self and life by analyzing adventure travel narratives.

\section{Literature Review}

\section{Adventure Travel}

Adventure travel is a broad term that has been used to describe a vast range of travel experiences from "soft adventure" to "hard adventure" (Adventure Travel Trade Association [ATTA] and George Washington University, 2013; Cater, 2013; Doran, 2016; Rantala, Rokenes, \& Valkonen, 2016; Varely \& Semple, 2015; World Tourism Organization [UNWTO], 2014). Adventure travel has often been described as having an element of perceived or real risk (Doran, 2016; Rantala et al., 2016), and travel that entails higher levels of risk is often referred to as "hard adventure" and "fast adventure" (Varley \& Semple, 2015). The risky activity is primary (Weber, 2001), and it is usually researched as an extension of adventure recreation and sport because the travel component is lacking and environment/destination is secondary (Weber, 2001). The other end of the adventure travel spectrum is referred to as "soft adventure" and is often described as a quest for insight and self-discovery (Bloom \& Goodnow, 2013; Borella, 2006; Campbell, 1968; Cousineau, 1998; Goodnow \& Ruddell, 2009; Moir-Bussy, 2003; Thursby, 2005; Walle, 1997). Elements of psychological risk are present, but the motive for this type of "slow adventure" (Varely \& Semple, 2015) is rarely to be challenged by physical risk or to experience "rush" (Buckley, 2012), but to seek insight (Walle, 1997; Weber 2001) and transformation (Reisinger, 2013). Adventure travel has also been conceptualized as frontier travel, where the frontier is defined by uncertainty. There is a:

connection between travel and 'travail' whereby the excitation of new experiences combines with the strain of being away from home to create the emotional territory that tourism provides for. It is this extraordinary dimension that provides the potential for adventure and, at one level, all travel and tourism is an adventure. (Beedie, 2008, p. 175)

Following Beedie's conceptualization of adventure travel, this study defined adventure travel to 
include the entire range of travel experiences from the hard to the soft.

\section{Insight}

Insight is commonly defined as the sudden solution to a previously unsolvable problem or longstanding state of discontent (Dunlap \& Yerkes, 1931; Levitt et al., 2004; Smith, Ward, \& Finke, 1995). Colloquially, insight is described as a "Grand Aha"- the moment of catching on or getting the point (Flanagan, 1997). Insight is a powerful, sudden moment of consciousness resulting in a "vivid, surprising, benevolent and enduring personal transformation” (Miller \& Bacca, 2001, p. 4). It's a process involving four stages: preparation, incubation, illumination, and verification (Miller \& Bacca, 2001). Preparation is a state of conflict or discontent characterized by an extended period of time spent failing to solve the problem and feeling frustrated. People can become fixated on using traditional ideas or past problemsolving techniques that do not work (Dominowski, 1981). These include unconscious rules, structures, and norms.

Fixation is often caused by environmental, emotional, and cultural blocks (Adams, 1974). Some common environmental blocks are phone calls; texts; noisy offices or work spaces; constant interruptions; social media applications such as Twitter, Facebook, Pinterest, Snapchat; and a harried pace. These distractions interrupt incubation, the second phase of the insight process where the unconscious mind works to solve problems. Emotional blocks are composed of fear of making mistakes, failing, or taking risks (Adams, 1974); fear associated with questioning nontraditional thinking (Flanagan, 1997); and fear associated with consequences of nonconformity and violating societal norms. Cultural blocks are imposed by the norms and expectations of one's culture.

The second stage of the insight model is incubation wherein active problem solving is abandoned and one's attention is focused elsewhere. However, during incubation the subconscious may be working on the problem and restructuring may occur (Dunlap \& Yerkes, 1931). Illumination, the third phase, is characterized by an involuntary sudden solution that occurs at a time when one is not focusing on the problem (Schooler \& Melcher, 1995).

\section{Liminality}

Liminality comes from the Latin word limen, meaning "a threshold," and was first described in Van Gennep’s (1960) seminal writing on rites of passages in indigenous cultures (Brooker \& Joppe, 2014; Rudwick, 1996). Turner (1966) described liminality as antistructure, transition, and "as a time and place of withdrawal from normal modes of social action” (p. 167). The process of transition has three phases: separation, margin (limen), and aggregation (Bloom \& Goodnow, 2013; Knudsen, 1997; Turner, 1966; Weber, 2001). Separation is the detachment of the individual or group from a social structure or set of cultural conditions and is sometimes considered a normless state (Bui, Wilkin, \& Lee, 2014) where existing norms may be replaced by disorder, antistructure, and experimental behavior (Brooker \& Joppe, 2014). Turner (1966) described the liminal phase as a "moment in and out of time, in and out of social structure, generalized social bond that has ceased to be and has simultaneously yet to be fragmented into multiplicity of structural ties" (p. 96). The suspension of norms, social bonds, rules, and time allows for engagement with new ways of thinking and behaving without the usual consequences associated with breaking norms and rules in ordinary life and society. Aggregation, the last stage of transition, occurs after exploration and engagement within the limen is complete. Often, when one returns back to home society, it is with a new psychological perspective and often into a higher status, life stage, or role in life.

\section{Adventure Travel and Liminality}

Individuals engage in adventure travel for a variety of motivations. Buckley (2012) summarized over 50 previous studies of adventure travel participants and three main themes consisting of 14 different categories of motivation for adventure travel emerged. Swarbrooke, Beard, Leckie, and Pomfret (2003) suggested a range of motives including uncertain outcomes, danger and risk, challenge, anticipated rewards, novelty, stimulations and excitement, escapism and 
separation, exploration and discovery, absorption and focus, and contrasting emotions. It is important to keep in mind that escape, defined as a "change from routine of home or work” (Buckley, p. 962), is distinct from liminality. Escape can be regarded as a push motive to dissociate from a negative condition at home and work, whereas liminality is a pull motive to engage in a positive experience. The following paragraph illustrates how some travelers may attempt to escape home to experience liminality and gain insight.

Some young adults travel to gain insight when they are unsure of their career path, feel dissatisfied with their jobs, desire escape from mundane routines, defer decisions about marriage, or delay traditional adult responsibilities (Obenour, 2004; White \& White, 2004). This experience is often regarded as a rite of passage (Bell, 2002; Johnson, 2007). People who travel in midlife often travel to escape routine, engage in personal growth, acquire new meaning in life, engage in a process of transformation, mark a break, or change their habitual patterns in life (Reisinger, 2013; White \& White, 2004). In late adulthood, travel is often a pilgrimage (Knudsen, 1997) to make sense of life through selfactualization. Women often use travel to search for a preferred self, identity, self-empowerment, connection with others (Cockburn-Wootten, Friend, \& McIntosh, 2006; Wilson \& Harris, 2006), and release or freedom from gender roles and expectations (Cockburn-Wootten et al., 2006; Wilson \& Harris, 2006). Both men and women of all ages travel with the intent to shift their perceptions of self and world (Reisinger, 2013) and seek their authentic self (Johnson, 2007; Reisinger, 2013).

Weber (2001) noted that the process of liminality can be observed with adventure travelers when they "removed themselves both physically and symbolically from their normal structured world and their social group. The separation stage is followed by the entry into the state of antistructure where 'communitas’ can be experienced” (Weber, 2001, p. 369). Leaving the security, familiarity, and predictability of home can make adventure travelers more open to new and novel ideas (Bloom \& Goodnow, 2013; Goodnow \& Ruddell, 2009; Hollander, 2007; Horn, 2010; Obenour, 2004). Adler (1985) suggested that traveling may serve as a ritual aid in accomplishing separation (the first phase of liminality) from family and home society. Travelers are often motivated to separate themselves from ordinary life, seek answers to questions, and gain insight into self (Hollander, 2007; Noy, 2004; Reisinger, 2013; Shaffer, 2004).

The liminal qualities of travel may provide freedom from many of the blocks to insight, break fixation, and facilitate restructuring (Bloom \& Goodnow, 2013). Liminality constructed through travel may prevent fixation on traditional solutions that are often the result of false assumptions, conformity to group norms and rules, and fear of violating norms. Furthermore, travel may facilitate insight because dissonance encountered by travel requires new ways of thinking and must be dealt with in novel ways (Reisinger, 2013). Since travel often creates a sense of anonymity, travelers experiencing liminality may be able to metaphorically leave behind the pressure to conform to norms and expectations of work, family, and home society.

In sum, travel is sometimes used to make a change and demark a new phase of life from a previously unsatisfying one and to seek meaningful experiences as opposed to escapism, which may not result in lasting change or insights (Hirschorn \& Hefferon, 2013; Wilson \& Harris, 2006). Insight occurs in the limen, after separation occurs, when the traveler feels a sense of freedom and release from the social constraints, norms, and routines of everyday life of home and when they encounter new and novel ways of life and people. Liminal experience may be an avenue to confront the fears that often block insight: fear about understanding self, not belonging to a group or society, and violating class/group structures (Bloom \& Goodnow, 2013; Flanagan 1997). Adventure travel can challenge values and beliefs, enrich one's life by exposure to different cultures (Reisinger, 2013), and be a form of self-conquest (Cousineau, 1998). Hottola (2004) noted, "It is not uncommon that even during a short stay in a foreign country, some patterns of expectations and values do change. . . . Thus, values and norms of their original societal context may seem less appealing than before” (p. 460). Therefore, cultural distance may be attractive to some who are seeking an inner journey and may need or desire a lack of social norms to perform their inner journey. An outward journey can lead to an insightful inner journey resulting in engagement, growth, healing, 
and new freedom (Moir-Bussy, 2003). The liminal quality of travel may be the necessary characteristic for insight attainment to occur. Hence, a deeper look into the liminal quality of travel is necessary to understand the potential link between liminality and insight during travel.

\section{Adventure Travel Narratives, Liminality, and Insight}

Although insight has been studied within the realm of tourism and the liminal dimensions have been researched, there has been limited research examining the association between liminality and insight within the context of adventure travel narratives. This literature review makes the case that travelers may write about attaining insight and experiencing liminality during travel. It is important to keep in mind that not all travelers necessarily go beyond the separation phase. Travelers might escape home, but they may not experience a normless state. Liminality and insight will more likely occur if the travel experience is free from blocks to insight (e.g., cellphones, social media, text messages, pressure to conform). Thus, the purpose of this study was to determine if travel narratives include evidence of insight and liminality and if those constructs appear to be related. In addition, this study explored whether trip characteristics were related to liminality and insight by examining specific trip characteristics such as solo/group travel, travel motivation, gender, and cultural novelty.

The number of travel partners may influence liminal experience and insight. Research suggested that traveling solo or alone is beneficial because it provides a sense of freedom (Wilson \& Harris, 2006). Solo travel is expected to yield greater instances of liminal experience, whereas travel partners may inject their goals and expectations into the situation, thus producing many of the barriers to insight discussed above. Due to the presence of a travel partner, the primary traveler may feel the need to conform his/her thoughts and behaviors and may not experience liminality or insight.

Differing travel motivations may affect how travelers construct their travel experiences based on the intrinsic forces that "push" a traveler to leave home and "pull" a traveler to a particular destination (Awaritefe, 2004). The literature on travel motivation suggested that those looking to escape society, resolve a personal crisis, or seek answers may construct a travel experience that is different from a traveler who is motivated to challenge him or herself. These differences may affect whether travelers experience liminality or insight.

The travel literature also provided evidence of a potential gender effect. Women's narratives tend to focus on the metaphorical inner journey of selfdiscovery, exploration, and awareness with strong themes of escaping the constraints of society, family expectations, and norms (Thursby, 2005). Travel books written by female authors often include the construction of self through self-imposed exile and follow the structure of the quest genre (Borella, 2006). The liminal qualities of travel provide freedom from convention and conformity around gender roles and associated proper and respectable behaviors. Travel allows for freedom of mind, spirit, and, above all, freedom from family and societal pressure to conform to conventional gender norms (Friedman, 1989). Female travelers may attempt to construct a different type of travel experience to gain insight and escape the norms of Western society, thus moderating the relation between liminal experience and insight.

As previously stated, travelers who encounter novel cultures may feel increased freedom to act and think in new and novel ways because the host cultures expect travelers to be strange and foreign. Therefore, a traveler may feel less pressure to conform to the goals and priorities of their home cultures and may not feel the pressure to conform to the goals and priorities of the culture they are visiting. In addition, the fear to fail or make a mistake is also decreased around strangers as opposed to people at home. Furthermore, travelers who perceive that they are traveling to highly novel cultures may have higher instances of liminal experiences than those who visit cultures similar to their own.

Based on the theorized connections between travel, insight, and liminality, five hypotheses were tested:

H1: There is an association between liminal experience and insight.

H2: The association between liminal experience and insight will be moderated by whether one travels alone or with others. 
H3: The association between liminal experience and insight will be moderated by travel motive.

H4: The association between liminal experience and insight will be moderated by gender.

H5: The association between liminal experience and insight will be moderated by cultural novelty.

\section{Method}

\section{Sample}

This study conducted a content analysis of published travel narratives, sometimes referred to as travel biographies. Travel narratives are a "factual, first-person account of a journey undertaken by the authors" (Hooper \& Youngs, 2004, p. 2) that follows a particular pattern or structure that is linear and chronological. Within this study, the use of an editor was permissible, but the traveler's own story must have been told in his or her own voice. Using guidelines set forth by Krippendorff (2013), the unit of analysis was the published adventure travel book.

Following procedures set forth by Krippendorff (2004), the population of adventure travel books was identified. First, a key word search of "adventure travel narratives" at the Barnes and Noble website yielded 1,157 book titles. After a close scrutiny of the books, over 500 were unusable as they were not written in the first person. A key criterion for inclusion in the study were books written as first-person narratives, as evidence of liminal and insight experiences may be lost if a person recounts another's story in the third person. Books were eliminated due to duplicate titles, third-person voice, children's stories, compilation books, guidebooks, and works of fiction.

Another technique to determine the population of travel narratives was the inclusion of travel writings from Sam Weller's bookstore in Salt Lake City. There is a section of travel writings that includes books that are out-of-print as well as new publications. This selection of adventure travel narratives is considered the largest and most comprehensive in the geographic area of the primary researcher. In addition, books on the shelves are easily accessible to the general public or the intended audience/ market. Sam Weller's also provided a list of titles of adventure travel writing beginning with the book with the greatest demand down to that of the least. Approximately 1,100 titles were included in the list. However, after an initial screening of titles, 156 were eliminated due to the criteria mentioned above.

There is no standard for choosing a sample size, only that the sample must be large enough to answer one's research questions (Krippendorff, 2004). The current study preformed a cluster sample of 50 books (between $5 \%$ and $10 \%$ of population) from the shelves of Sam Weller's travel writing section (30 books) and Barnes and Noble Bookstore (20 books). The sample size was chosen to ensure enough saturation of emergent themes. At each bookstore, the primary researcher assigned each book a number, starting from the beginning of the travel narrative section (authors with last name beginning with $\mathrm{A}$ ) and working their way to the end of the section. Using a randomization technique, the numbers on the list were matched up with the travel narratives. Those matching books were chosen to be part of the sample. However, if the travel narrative did not meet the criteria for "adventure travel narrative," the book directly after it was selected. If the second book did not meet the "adventure travel narrative" criteria, then the book directly preceding the original book was chosen. Table 1 is a list of the 50 adventure travel narratives that were coded for this study.

\section{Data Analysis}

Content analysis was utilized to analyze the selected travel narratives. Content analysis involves "the systematic reading of a body of texts, images and symbolic matter (Krippendorff, 2013, p. 10) and is useful in exploratory studies to more fully understand the variables being studied and to retain the richness found within the text” (Krippendorff, 2013). This study utilized two stages of content analysis. First, a qualitative approach was used to create categories through reading, annotating, and assigning codes to data to develop a code book that would be used to identify the presence or nonpresence of variables within adventure travel narratives. Corbin and Strass (2008) proposed three phases of coding: open coding, axial coding, and selective coding. The first, open coding, is conducted to identify reoccurring words, themes, and concepts. Axial coding identifies the relationships among 
Table 1

List of Travel Narratives

\begin{tabular}{|c|c|c|c|}
\hline Author & Date & Title & Publisher \\
\hline Adams, $\mathrm{N}$. & 2002 & Far Appalachia: Following the New River North & Delta \\
\hline Alexander, L. & 1988 & $\begin{array}{l}\text { Six Months off: An American Family's Australian } \\
\text { Adventure }\end{array}$ & William Morrow \& Co. \\
\hline Ballingall, J. & 1984 & A Taste of China & F. Watts \\
\hline Barich, B. & 1995 & Big Dreams: Into the Heart of California & Vintage Books \\
\hline Blake, B. W. & 1953 & I'll Take the High Road & Regnery Publishing, Inc. \\
\hline Bird, L. & 1997 & $\begin{array}{l}\text { Sonnet: One Woman's Voyage From Maryland to } \\
\text { Greece }\end{array}$ & North Point Press \\
\hline Botello, J. G. & 1998 & The Other Side: Journeys in Baja California & Sunbelt Publications \\
\hline Brook, S. & 1987 & Maple Leaf Rag: Travels Across Canada & Vintage Books \\
\hline Brooks, P. & 1966 & Roadless Area & Knopf \\
\hline Bryson, B. & 1998 & Neither Here nor There: Travels in Europe & Black Swan \\
\hline Chapple, S. & 1993 & $\begin{array}{l}\text { Kayaking the Full Moon: A Journey Down the } \\
\text { Yellowstone River to the Soul of Montana }\end{array}$ & HarperCollins Publishers \\
\hline Chatwin, B. & 1988 & The Songlines. & Penguin Books \\
\hline Cosentino, F. J. & 1984 & $\begin{array}{l}\text { The Boehm Journey to Ching-Te-Chen, China, } \\
\text { Birthplace of Porcelain }\end{array}$ & Edward Marshall Boehm \\
\hline Eliot, A. & 1962 & $\begin{array}{l}\text { Earth, Air Fire and Water: A Personal Adventure into } \\
\text { the Sources of our Life and Legend }\end{array}$ & Simon and Schuster \\
\hline Erdman, S. & 2003 & Nine Hills to Nambonkaha & Henry Holt \& Co. \\
\hline Evans, P. & 2003 & It's Not About the Tapas & Bantam \\
\hline Evans, $\mathrm{P}$. & 2006 & $\begin{array}{l}\text { Fried Eggs With Chopsticks: One Woman's Hilarious } \\
\text { Adventure into a Country and a Culture Not Her Own }\end{array}$ & Delta Books \\
\hline Fletcher, C. & 1997 & $\begin{array}{l}\text { River: One Man's Journey Down the Colorado, Source } \\
\text { to Sea }\end{array}$ & Knopf \\
\hline Firestone, C. & 1938 & Sycamore Shores & National Travel Club \\
\hline Frazier, I. & 1990 & Great Plains & Penguin \\
\hline Goodwin, J. & 1993 & On Foot to the Golden Horn: A Walk to Istanbul & Chatto \& Windus \\
\hline Hansen, E. & 1989 & Stranger in the Forest: On Foot Across Borneo & Penguin \\
\hline Heat-Moon, W. L. & 1999 & River-Horse: The Logbook of a Boat Across America & Houghton Mifflin \\
\hline Heuer, K. & 2002 & $\begin{array}{l}\text { Walking the Big Wild: From Yellowstone to the Yukon } \\
\text { on the Grizzly Bear's Trail }\end{array}$ & $\mathrm{M} \& \mathrm{~S}$ \\
\hline Javins, M. & 2006 & $\begin{array}{l}\text { Stalking the Wild Dik-dik: One Woman's Solo Mis- } \\
\text { adventures Across Africa }\end{array}$ & Seal Press \\
\hline Jenkins, P. & 1979 & A Walk Across America & Morrow \\
\hline Keenan, B. & 2006 & Four Quarters of Light & Broadway Books \\
\hline Lewis, C. & 1996 & Around the World in Seventy-nine Days & Delta Pub \\
\hline Linnea, A. & 1995 & Deep Water Passage: A Spiritual Journey at Midlife & Little Brown \\
\hline McGregor, E., \& Boorman, C. & 2005 & Long Way Round & Time Warner Books \\
\hline Moore, J. H. & 1965 & Tears of the Sun-god & Faber \& Faber \\
\hline Packer, J. & 1966 & The World is a Proud Place & Dutton \\
\hline Nugent, R. & 1991 & The Search for the Pink-Headed Duck & Houghton, Mifflin \\
\hline Salak, K. & 2001 & $\begin{array}{l}\text { Four Corners: A Journey into the Heart of Papua New } \\
\text { Guinea }\end{array}$ & National Geographic \\
\hline Sand, G. & 1978 & Winter in Majorca & Academy Press Limited \\
\hline Schnell, J. & 1994 & Both are Better: Travels in Britain and France & Milner Press \\
\hline Schiffer, M. & 1980 & Lessons of the Road-an Overland Journey to the East & Kenan Press \\
\hline Severgnini, B. & 1995 & Ciao, America: An Italian Discovers the US & Broadway \\
\hline Smith, A. & 1963 & Jambo African Balloon Safari & Dutton \& Co \\
\hline Theroux, P. & 1993 & The Happy Isles of Oceania: Paddling the Pacific & Fawcett Books \\
\hline Thorpe, N. & 2002 & $\begin{array}{l}8 \text { Men and a Duck: An Improbable Voyage by Reed } \\
\text { Boat to Easter Island }\end{array}$ & Free Press \\
\hline Trillin, C. & 1989 & Travels with Alice & Ticknor \& Fields \\
\hline Troost, $\mathrm{M}$. & 2004 & $\begin{array}{l}\text { The Sex Lives of Cannibals: Adrift in the Equatorial } \\
\text { Pacific }\end{array}$ & Broadway Books \\
\hline Van der Post, L. & 1958 & The Lost World of the Kalahari & Hogarth Press \\
\hline Voiland, B. & 1995 & Hurt City & Bike Enterprises \\
\hline
\end{tabular}


Table 1 (Continued)

\begin{tabular}{lccl}
\hline Author & Date & Title & Publisher \\
\hline Walker, D. & 1980 & $\begin{array}{c}\text { Fool's Paradise: One American's Search for Vestiges } \\
\text { of an Ancient Culture in Modern-day Saudi Arabia }\end{array}$ & Bloomsbury Publishing \\
Walker, V. & 2007 & $\begin{array}{c}\text { Mantras \& Misdemeanours: An Accidental Love Story } \\
\text { Wheeler, S. }\end{array}$ & $\begin{array}{l}\text { Allen \& Unwin } \\
\text { Winternitz, H. }\end{array}$ \\
\hline
\end{tabular}

and between codes and forms categories. Categories are variables or themes that emerge from the data and context. As additional coding continues, consistent categories should emerge from the data. Selective coding created the core categories and definitions used to create the code book. The code book was used in the second phase of content analysis to identify the presence or nonpresence of insight, liminality, and other key variables.

All variables used in this study are categorical and coded simply in terms of present or absent. Although insight is conceptually an implicit dependent variable, neither the literature review nor study method warrants causality, thus directionality cannot be assured. As such, an associational approach to the data analysis was taken. A simple chi-square test was used to test for association. Hierarchical log linear modeling was then used to test these associations (Von Eye \& Mun, 2013). Log linear modeling is a statistical procedure that allows for tests of association in multiway contingency tables. It tests for the co-occurrence of two events in the same narratives by predicting cell frequencies of one variable based on associations among other variables. Such a strategy allows for testing the study's main hypothesis regarding the association between insight and liminal experience as found in the text. Log linear analysis also allowed researchers to examine the more complex three-way associations that this study required. Each model combines all instances of each variable rather than a specific type. For example, the variable insight represented all instances of insight in a text rather than specific types of insight such as self-insight or spiritual insight.

\section{Development of Codebook}

A content analysis codebook is a document that outlines and describes to coders how to systematically identify the presence or nonpresence of variables within each adventure travel narrative and how to code each variable (Krippendorff, 2004). This technique acknowledges that a well-formulated codebook is intended to "explicate rules that minimize the use of subjective judgments in the recording process, without denying the participants of human abilities” (Krippendorff, 2004, p. 126). In addition, the codebook would enable future researchers to replicate this study. An in-depth literature review of liminality, insight, and the context of travel was used to create operational definitions of insight, liminality, and variables that may influence or moderate insight, liminality, or both. Additional variables that emerged from the literature review included number of travel partners, travel motives, gender, and level of cultural novelty.

Following a review of the literature, the second phase of developing the codebook was an analysis of 12 adventure travel narratives by the primary researcher. The primary researcher, identified emergent major themes related to insight, liminal experience, and barriers to insight. Tables 2 and 3 contain examples from the codebook, including the operational definitions, themes, and categories of the study's main variables.

After the codebook was completed, it was necessary to determine if it informed coders how to identify and code variables correctly and reliably. Therefore, using the codebook, two coders and the primary researcher coded the same 12 books. Results suggested that the codebook was ready for pilot testing to establish and determine reliability: stability, reproducibility, and accuracy. Lombard, SnyderDuch, and Bracken (2002) suggest that intercoder reliability "coefficients of 0.90 or greater are nearly always acceptable, 0.80 or greater is acceptable in most situations, and 0.70 may be appropriate in some exploratory studies for some indices” (p. 600). 
Table 2

Codebook Operational Definitions

\begin{tabular}{|c|c|}
\hline Operational Definition & Expanded Description for Coders \\
\hline $\begin{array}{l}\text { Liminal Experience: A feeling of being } \\
\text { in a place or time of transition, neither } \\
\text { here nor there, or a place in between. }\end{array}$ & $\begin{array}{l}\text { An experience where normal limits to thought, self-understanding, and behavior are } \\
\text { relaxed and one may be open to something new. } \\
\text { One may feel that the rules don't apply or that there are no expectations to act, } \\
\text { think, or be a certain way. } \\
\text { One may feel a release or the ability to disengage from normal daily routines, goals, } \\
\text { and priorities. }\end{array}$ \\
\hline $\begin{array}{l}\text { Insight: Described as a sudden solution } \\
\text { to a problem, an answer to a problem } \\
\text { or concern. }\end{array}$ & $\begin{array}{l}\text { An Aha! moment, an understanding of how a problem is solved, a moment of } \\
\text { catching on or getting the point, a flash or sudden illumination, and when meaning } \\
\text { becomes perfectly clear. }\end{array}$ \\
\hline
\end{tabular}

Initially, interrater reliability between the two coders was calculated, but reliability levels were not acceptable for several variables. Therefore, the codebook was modified and revised, and coders received additional training. Following codebook modification and coder training, 10 new randomly selected books were coded and a second pilot test was performed. Interrater reliability of the 10 new books using the revised codebook was calculated and was considered acceptable for all variables. As interrater reliability for all variables was $r=0.80$ (Cronbach's $\alpha$ ) or higher, coding of the rest of the sample commenced.

The second phase utilized a quantitative approach where coders utilized the codebook to identify whether liminality, insight, and other variables were present or absent. Variables were considered present when at least one theme was coded as present. For instance, if a narrative was coded as containing a description of self-insight, then it met the criteria for insight. Neither frequencies nor the type of insight or liminality was relevant for this current study as the purpose of this research was to identify if there was an association between insight and liminality, in general, and if specific variables, such as gender, number of travelers, type of motivation, and cultural novelty, might influence the proposed association.

\section{Results}

\section{Descriptive Statistics}

Seventy-four percent of travel narrative authors were male, and their ages during travel ranged from 20 to 67 years of age (34\% did not identify their age). Travelers in the narratives were evenly split between traveling solo (50\%) and traveling with others (50\%). Trip length ranged from 1 month to several years and most traveled independently without the use of a guide (82\%), and $18 \%$ traveled with the help of a guide or on a packaged tour. Most authors traveled by motorized transportation (62\%), foot (12\%), kayak (8\%), sailboat (8\%), bicycle (6\%), canoe $(2 \%)$, and hot-air balloon (2\%) and took place in nature $(88 \%)$ and in areas with medium-to-high cultural novelty. The majority of travel authors described their travel motives as being to test or push one's self or to prove something (50\%), followed by to escape or separate from life and society (36\%), to seek answers (20\%), to resolve a crisis (18\%), or to gain a spiritual experience (12\%). In addition, there were some travelers who described multiple travel motives.

Slightly over one-half (54\%) of the adventure travel narratives contained reports of an insight experience. Of the narratives that contained insight experiences, $51.9 \%$ reported self-insight, $44.4 \%$ reported lifestyle insight, and $51.9 \%$ reported spiritual insight. These results suggest that a single adventure travel narrative can report several types of insight experience during the same trip.

Liminal experience was identified in $62 \%$ of the adventure travel narratives. Of the narratives identified as containing liminal experience, $83 \%$ described feelings of being physically away, $41 \%$ described feelings of being cognitively away, and $25.8 \%$ described feelings of being psychologically away. Several types of liminal experience were identified as occurring in the same narrative. 
Table 3

Codebook Themes and Categories

Categories

\section{Insight Themes}

Self-Insight: The traveler realized something important regarding him/herself that he/she found significant or important.

Lifestyle Insight: Traveler discovered new ways to live life well. The traveler remarked that he/she figured out how to really or truly live. $\mathrm{He} / \mathrm{she}$ found the secret to living right.

Spiritual Insight: Spirituality is not limited to, but may include, a religious perspective/ experience. Spirituality may be a feeling that one is connected to or part of something greater and outside of one's self. It can also be a feeling of reverence for life, environment, and connection to environment.

\section{Liminality Themes}

Being Away Physical: The traveler feels as if he/she has entered into a new, novel, or different world.

Being Away Cognitive: Traveler disengages from the normal daily routines of ordinary life and spends his/her time on new and novel things.

Being Away Psychological: Travelers feel free to act, think, and be one's authentic self without concern of judgment from other people.
Discovered new personal strengths, weaknesses, and future potential; Discovered life's meaning, purpose, and direction;

Discovered one's place in the world, felt part of the world, and felt a connection to the world;

Paradigm shift (view of self or reality of self significantly changed, new perspective of self, and/or found authentic or true self).

Example from text: "Travel is life-changing. . . . Self-transformation is what I sought and what I found” (Eaves, 2011, p. 296).

Simple living is happy living;

Figured out how to be happy;

Importance of living in the moment;

Change in values and priorities regarding what is important in life;

Figured out how little one needs to be happy;

Paradigm shift (view of reality has changed, new perspective of life) regarding how to live life.

Example from text: "This journey taught me that we could happily get by with less-less money, less luxury, fewer status symbols, and far fewer belongings than we previously imagined” (Cohen, 2001, pp. 272-273).

Discovered basic truths or deeper understanding of truths;

Connection/reverence to higher power or outside one's self;

Connection/reverence to environment/nature.

Example from text: "I realized that taking a sight, plotting it with another sight, and finding a cross in the middle of the water void on a chart created an addictive feeling of mastery and connection with the Earth and the stars" (Aebi \& Brennan, 1989, p. 296).

Physical environment is different from home;

Experience in new environment is very different from home.

Example from text: "It was the place that had showed me, for the first time, that when you were somewhere else, you could be someone else" (Eaves 2011, p. 15).

Everyday routine is different;

Disengaged from normal activities such as commuting to work, working at a daily job, paying the bills, doing the laundry, and other chores or duties that make up the everyday life of one's society.

Example from text: "In order to ponder the course of my own life with any sense of perspective, I had to completely relinquish my routine-mentally as well as physically ... a after that I began to see aspects of my life and career with increased clarity, and only then could I reevaluate old patterns and assumptions” (Cohen, 2001, p. 207).

General feeling that one is free from all judgments of family, friends, society, and the culture visited;

Ability to disengage from goals and priorities of day-to-day life or those imposed by society, family or friends;

Feels permission to be true to self and that there are no arbitrary boundaries to confine thoughts or behaviors.

Example from text: "Once I leave the U.S., I am not bound by the rules of my culture. And when I am a foreigner in another country, I am exempt from the local rules. This extraordinary situation means that there are no rules in my life. I am free to live by the standards and ideas and rules I create for myself” (Gelman, 2007, p.40). 


\section{Hypothesis Tests}

There was a significant association between liminal experience and insight $\left(\chi^{2}=14.034, p<0.001\right)$. An association between insight and liminal experience was tested in a two-way contingency table using the chi-square statistic. The standardized residuals in Table 4 suggest that authors who wrote about having insights also wrote about having liminal experiences. Conversely, those authors who did not write about insight experiences likewise did not write about liminal experiences.

In addition to testing for an association between liminal experience and insight, another purpose of this study was to analyze three-way associations among insight, liminal experience, and other selected variables suggested in the literature. These variables might moderate the insight by liminal experience association found in the narratives. These associations were examined using hierarchical log linear modeling. Each model combines all instances of each variable rather than a specific type. For example, the variable insight represented all instances of insight in a text rather than specific types of insight such as self-insight or spiritual insight. Only one of several three-way associations among liminal experience, insight, and related variables (number of travelers, travel motive, sex of traveler, and level of cultural novelty) resulted in a significant three-way association (see Table 5).

There was a significant three-way association among insight, liminal experience, and travel motivation (escape, seek answers, resolve a crisis, spiritual experience, and test one's self). A separate hypothesis test was performed for each travel motive with liminal experience and insight. Only the three-way

Table 4

Insight by Liminal Experience

\begin{tabular}{lccl}
\hline & No Liminal & Yes Liminal & Total \\
\hline No insight & & & \\
$\quad$ Count & 15 & 8 & 23 \\
$\quad$ Expected count & 8.7 & 14.3 & 23.0 \\
$\quad$ Std. residual & 2.1 & -1.7 & \\
Yes insight & & & \\
$\quad$ Count & 4 & 23 & 27 \\
$\quad$ Expected count & 10.3 & 16.7 & 27.0 \\
$\quad$ Std. residual & -2.0 & 1.5 & \\
\hline
\end{tabular}

Table 5

Summary of Hypothesis Test Results

\begin{tabular}{lc}
\hline Hypothesis & Result \\
\hline $\begin{array}{l}\text { H1: There will be an association between } \\
\text { liminal experience and insight. }\end{array}$ & Null rejected \\
H2: There will be a three-way association & Null retained \\
between liminal experience, insight, and & \\
solo travel. & \\
H3a: There will be a three-way association & Null rejected \\
between liminal experience, insight, and & \\
travel motive-escape. & \\
$\begin{array}{l}\text { H3b: There will be a three-way association } \\
\text { between liminal experience, insight, and }\end{array}$ & Null retained \\
travel motive-seek answers & \\
$\begin{array}{l}\text { H3c: There will be a three-way association } \\
\text { between liminal experience, insight, and }\end{array}$ & Null retained \\
travel motive-resolve a crisis & \\
$\begin{array}{l}\text { H3d: There will be a three-way association } \\
\text { between liminal experience, insight, and }\end{array}$ & Null retained \\
travel motive-seek spiritual experience & \\
$\begin{array}{l}\text { H3e: There will be a three-way association } \\
\text { between liminal experience, insight, and }\end{array}$ & Null retained \\
travel motive- test one’s self & \\
$\begin{array}{l}\text { H4: There will be a three-way association } \\
\text { between liminal experience, insight, and }\end{array}$ & Null retained \\
gender. & \\
$\begin{array}{l}\text { H5: There will be a three-way association } \\
\text { between liminal experience, insight, and } \\
\text { cultural novelty }\end{array}$ & Null retained \\
\hline
\end{tabular}

association among insight, liminal experience, and escape was significant $(z=-1.971, p=0.049)$. Motivation to escape moderated the association between liminal experience and insight. Narratives in which the traveler was motivated to escape described the association between insight and liminal experience differently than those who were not motivated to escape. The three-way crosstab table indicates a 3.5 standardized residual in the "yes escape motive," "no liminal experience" and "no insight" cell. The means that the combination of no mention of liminal experience and no insight is overrepresented by those narrating escape motives (Table 6).

In sum, the results of the content analysis of travel narratives suggested that there is an association between liminality and insight. That association was moderated by only one variable: escape motive. All other three-way associations among liminal experience, insight, and travel motive (seeking answers, resolving a crisis, gaining a spiritual experience, and testing one's self) resulted in nonsignificant threeway associations. 
Table 6

Escape by Insight by Liminal Experience

\begin{tabular}{lllcc}
\hline Escape & Insight & & No Liminal & Yes Liminal \\
\hline No & \multirow{2}{*}{ No } & Count & 12 & 8 \\
& & Expected count & 10 & 10 \\
& & Std. residual & 0.6 & -0.6 \\
No & \multirow{2}{*}{ Yes } & Count & 4 & 8 \\
& & Expected count & 6.0 & 6.0 \\
& & Std. residual & -0.8 & 0.8 \\
Yes & \multirow{2}{*}{ No } & Count & 3 & 0 \\
& & Expected count & 0.5 & 2.5 \\
& & Std. residual & 3.5 & -1.6 \\
\hline
\end{tabular}

\section{Discussion}

\section{Interpretation of Results}

Results support a significant association between liminal experience and insight in this sample of travel narratives. Liminal experience and insight generally occurred together as authors rarely described a liminal experience without insight attainment or insight attainment without a liminal experience. Only 15\% of those who wrote about insight did not write about liminality. One might make a tentative conclusion that liminality may facilitate insight experience.

It was proposed that travel authors who traveled solo would be more likely to describe liminal experience and insight within their travel narratives, whereas travel authors who traveled with others would not be as likely to describe liminality and insight together. However, this was not the case. Authors who traveled solo did not describe more instances of liminal experience or insight experience when compared to authors who did not travel solo. Both those who wrote about traveling solo and traveling in a group connected liminal experience and insight in a similar manner and with similar frequency within their narratives.

Past research regarding travel both supported and contradicted this finding. For example, some research suggested that those who travel in groups can and do experience liminality (Bruner, 1991; Lett, 1983), while other research suggested that a solo experience is important for insight (Hammond, 2005; Knapp \& Smith, 2005). Turner (1966) asserted that "normative communitas" is formed within liminality and that normal norms and structures are suspended and then replaced by new ones. The new structures are often considered antistructured, yet thought to promote human flourishing and optimal social conditions (Horn, 2010). Bobilya (2005) suggested that an individual's state of mind and internal stimulus are more important in experiencing solitude than whether people are in a solo state or among others. This may, in part, explain the nonassociation. What is important to note is that liminal experience was related to insight whether the traveler was solo or traveling with others.

Within the sample of travel narratives, the authors' travel motives were expected to moderate the association between liminal experience and insight. The only travel motive that was significantly associated with liminal experience and insight was escape. It was thought that the travel authors who described being motivated to escape life and society (boredom, repetition, monotony, ordinary life, dissatisfaction with work and school, and group and societal norms and expectations) would construct a liminal experience that is different from ordinary life-free from work, school, and the norms and expectations of one's home and society-and gain insight. Surprisingly, those seeking to escape mentioned liminal experience and insight to a lesser extent than travelers motivated by other reasons. Future research should explore if those seeking to escape through travel experience lower levels of liminality and insight and, if so, why.

The hypothesized three-way association between liminal experience, insight, and sex of the traveler within travel narratives was not supported. It was proposed that female travel authors suffer more pressure to conform to conventional norms than males (Friedman, 1989) and may have a greater need for liminal experience and insight. Women often expect travel to result in a dramatic life change, such as a new perspective, attainment of authentic self, and new life meaning (Wilson \& Harris, 2006) whereas men often look for an outlet to be a hero (Gilbert \& Abdullah, 2004). However, Noy (2004) stated that within both male and female narratives there is talk of profound change and insight from long-term travel, and Johnson (2007) suggested that men were also seeking their authentic selves because modern man is alienated and must find it elsewhere, such as within a traditional culture. Reisinger (2013) did not distinguish a difference between male and female 
travel experience. A final explanation for the lack of support for the three-way association may also be that only $26 \%$ of the sample was written by female travel writers whereas $74 \%$ of the sample was written by male travel writers. It is possible that the low number of travel books written by female authors was too small to detect a significance difference.

The hypothesized three-way association was between liminal experience, insight, and cultural novelty within travel narratives. It was proposed that high cultural novelty would be associated with liminality or new context. The perception of being in a new and novel world may provide a greater chance to gain new information, reconsider earlier knowledge, and provide an environment open to creativity and insight (Hottola, 2004). Most travelers, whether traveling solo or with others, spend the majority of their time with other travelers they meet on the road. They spend very little time interacting with host cultures (Sorensen, 2003). In addition, travelers create their own travel culture complete with norms and rules of acceptable behavior (McCabe \& Stokoe, 2004; Shaffer, 2004; Sorensen, 2003).

In sum, travelers experienced liminality and insight regardless of their gender/sex, travel partners, or level of cultural novelty encountered. However, those who were motivated to escape experienced less liminality and insight than those who were motivated by other reasons.

\section{Limitations}

This study had several limitations. First, the small sample size of 50 adventure travel narratives may have impacted the power to reject the null if the null is false (type II error). For instance, frequencies for some categories were quite low. In addition, the adventure travel narratives that comprise this sample represented a wide spectrum of adventure travel narratives. Each trip type varied greatly from the others. The variability of the trip types in addition to the small sample size may have contributed to type II error.

Second, this study utilized content analysis, a form of correlational research, thus causality among the study's variables cannot be assumed. It is tempting to assume, based on the literature review and the results of the tests of association, that liminal experience may cause insight to occur; however, the research design cannot allow for that inference. Hence, this study can only infer that associations exist within adventure travel narratives, and results of this study can only be generalized to published adventure travel narratives and not to adventure travelers.

Third, the evidence of insight and its association with travel is open to question. The purpose of most travel narratives is to be published and to incur profit. Therefore, it is not known how much of the story has been edited to fit the needs of publishing to the detriment of the actual evidence or story; the travel author's experience may have been edited to fit the genre (Goodnow \& Ruddell, 2009). The association between liminality and insight may exist only within the realm of travel narratives and may not be present in the traveler's actual experience.

\section{Implications for Practice}

Results of this study provide several implications for practice. There is a spectrum of people who read adventure travel narratives. At one end are the armchair travelers, who live vicariously through the travels depicted in the narratives (Wilson \& Richards, 2004). On the other end are the readers who are inspired by them to travel (Dann, 1996; Wilson \& Richards, 2004), to re-create the very same experience (Laing \& Crouch, 2011), or to travel to particular destinations and engage in particular travel styles (Wilson \& Richards, 2004). The results of this study suggest that insight and liminal experience are major themes within adventure travel writing. Thus, many readers of adventure travel narratives, regardless of their place within the spectrum, may expect to gain insight if they choose to travel. Readers who become travelers may also intentionally design their travel experience to gain insight (Goodnow \& Ruddell, 2009; Walle, 1997).

The travel industry should continue to recognize the influence of travel narratives on travel behavior and expectations. Dann (1999) suggested that adventure narratives may be responsible for "setting the tourist agenda” (p. 161). Travel and tour companies could capitalize on the idea of gaining insight through travel by designing tour packages that center around the themes of insight and liminality. This can be accomplished by creating a liminal-type experience where travelers feel 
separated or suspended from their regular routine and daily grind and feel as if they are in a new and novel world. This might be achieved by utilizing novel activities, designing slow tourism experience (Fullagar, Markwell, \& Wilson, 2012) with ample time to think and reflect upon their experiences, and traveling to destinations that are physically, environmentally, or culturally different from home (Bloom \& Goodnow, 2013; Reisinger, 2013). In particular, in narratives where the travelers wrote about being motivated to escape negative associations with home, liminality and insight were more elusive than those motivated by other reasons. If reality mimics travel narratives, travelers motivated by escape may need additional support and specific tour design to help them truly escape from home. Tour companies may want to market and design travel experiences where it is difficult and not the norm to check in with home or work. Tour design should focus on "giving permission" for travelers to be present and in the moment and dissuaded from letting their thoughts dwell to stresses at home. Furthermore, creating the norm that suggests communication with home or work is not acceptable may help those travelers be present in travel experience.

\section{Implications for Future Research}

Future research might focus on building on the results of this study as well as reducing the limitations previously discussed. For instance, type II error may be associated with high variability in trip type and small sample size. Future research should replicate this study using a large sample of travel narratives restricted to an adventure type such as long-term bicycling journeys, backpacking historical routes, or driving tours across continents. Narratives that have less variability within trip type could be useful for fleshing out relationships among important variables.

Within the current study there is a statistical association between writing about liminality and writing about insights (both self-perceived) within 50 published travel narratives. This significant relationship suggests that it would be worth studying whether adventure tourists, in general, perceive liminality, insights, and/or both. However, it is still not known if it is travel itself that generates these perceptions, because only travel narratives were analyzed. There are other stories, unrelated to travel, that are about the quest to see one's life differently. Thus, researchers need to ask tourists if and how travel changed their attitudes to life.

\section{Conclusion}

Travel narratives can inspire and influence readers in a variety of ways. Indeed, some readers are inspired to recreate the travel experience, including where to travel, how to travel, and what to expect during travel (Dann, 1999; Goodnow \& Ruddell, 2009; Laing \& Couch, 2011; Wilson \& Richards, 2004). As early as the 19th century, travel narratives were thought to be centered on the theme of self-discovery, described through the metaphors of the hero's quest and inner journey (Borella, 2006; Goodnow \& Ruddell, 2009; Thursby, 2005). The inward journey is a search for understanding, personal insights, and freedom (Thursby, 2005). Thus, the purpose of this study was to identify if insight attainment and liminality are current themes of adventure travel narratives, if they are associated, and what may modify the proposed association.

Results of this study suggest that both liminality and insight attainment are major themes of adventure travel narratives, as liminality was described in $62 \%$ of narratives and insight was reported in $54 \%$ of narratives. More importantly, insight attainment and liminality were significantly associated within the same narrative. Readers may expect to gain insight through travel, and they may attempt to construct liminal experience in order to gain insight. Therefore, researchers and practitioners should seek to understand how narratives that describe the association between liminality and insight might influence readers who choose to travel. Do readers expect to gain insight about life and self through travel? Do they expect to gain insight through engaging in package tours? Do they intentionally design travel components, engage in particular travel styles, and choose destinations with the hope of conducting their own journey of insight and liminality? If readers design their travel around these expectations, how do they react if their travel experience deviates from their expectations? Results of this study also indicate that cultural novelty, number of travel partners, and travelers' gender did not moderate the association between insight and liminality, whereas 
travel motivation did moderate the association. Travel authors who wrote about being motivated by escape wrote about insight and liminality less than those motivated for other reasons. Future research should explore why those seeking to escape may have found liminality and insight to be elusive. Why is this the case and how might the travel experience be modified to help those seeking escape also experience liminality and insight? These are some of the unanswered questions that researchers and practitioners should seek to answer regarding the influence of the adventure travel narrative on its readers and the travel and tourism field.

\section{References}

Adams, J. (1974). Conceptual blockbusting. Stanford, CA: Stanford Alumni Association.

Adler, J. (1985). Youth on the road: Reflections on the history of tramping. Annals of Tourism Research, 12(3), 335-354.

Adventure Travel Trade Association and George Washington University. (2013). Adventure tourism market study 2013. Retrieved from http://files.adventuretravel.biz/ docs/research/adventure-tourism-market-study-2013web.pdf

Aebi, T., \& Brennan, B. (1989). Maiden voyage. New York, NY: Ballantine Books.

Awaritefe, O. D. (2004). Motivation and other considerations in tourist destination choice: A case study of Nigeria. Tourism Geographies, 6(3), 303-330.

Beedie, P. (2008). Adventure tourism as 'new frontier' in leisure. World Leisure Journal, 50(3), 173-183. doi:10.1080/ 04419057.2008.9674551

Bell, C. (2002). The big 'OE': Young New Zealand travelers as secular pilgrims. Tourist Studies, 2(2), 143-158. doi:10.1177/146879702761936635

Bloom, K., \& Goodnow, J. (2013). Insight and the travel experience: An exploration into the contributions of liminality. Journal of Travel and Tourism Research (online), 13(1/2), 143-157.

Bobilya, A. J. (2005). Wilderness, solitude, and monastic traditions. In C. E. Knapp \& T. E. Smith (Eds.), Exploring the power of solo, silence, and solitude (pp. 61-74). Boulder, CO: Association for Experiential Education.

Borella, S. S. (2006). The travel narratives of Ella Maillart: (En)gendering the quest. New York, NY: Peter Lang.

Brooker, E., \& Joppe, M. (2014). Developing a tourism innovation typology: Leveraging liminal insights. Journal or Travel Research, 53(4), 500-508.

Bruner, E. M. (1991). Transformation of self in tourism. Annals of Tourism Research, 18, 238-250. doi:10.1016/ 0160-7383(91)90007-X

Buckley, R. (2012). Rush as a key motivation in skilled adventure tourism: Resolving the risk recreation paradox. Tourism Management, 33, 961-970.
Bui, H., Wilkin, H., \& Lee, Y. (2014). Liminal experience of East Asian backpackers. Tourist Studies, 14(2), 126-143.

Campbell, J. (1968). The hero with a thousand faces. New York, NY: Princeton University Press.

Cater, C. (2013). The meaning of adventure. In S. Taylor, P. Varley, \& T. Johnston (Eds.), Adventure tourism: Meanings, experience and learning (pp. 7-18). London, UK: Routledge.

Cockburn-Wootten, C., Friend, L., \& McIntosh, A. (2006). A discourse analysis of representational spaces: Writings of women independent traveler. Tourism, 54(1), 7-16.

Cohen, D. E. (2001). One year off. San Francisco. CA: Traveler's Tales.

Corbin, J. \& Strass, A. (2008). Basics of qualitative research: Techniques and procedures for developing grounded theory (3rd ed.). Thousand Oaks, CA: Sage.

Cousineau, P. (1998). The art of pilgrimage: The seeker's guide to making travel sacred. York Beach, ME: Conari Press.

Dann, G. (1999). Writing out the tourist in space and time. Annals of Tourism Research, 26(1), 159-187.

Dominowski, R. L. (1981). Comment on "An examination of the alleged role of 'fixation' in the solution of several 'insight' problems” by Weisberg and Alba. Journal of Experimental Psychology: General, 110(2), 203.

Doran, A. (2016). Empowerment and women in adventure tourism: A negotiated journey. Journal of Sport and Tourism, 20(1), 57-80. doi:10.01080/14775085.2016. 1176594

Dunlap, K., \& Yerkes, R. (1931). Reasoning in humans. The Journal of Comparative Psychology, 12, 181-194.

Eaves, E. (2011). Wanderlust: A love affair with five continents. Berkeley, CA: Seal Press.

Flanagan, J. (1997). Quest for self-knowledge: An essay in Lonergan's Philosophy. Toronto: University Press.

Friedman, S. (1989). Exile in the American grain: H.D.'s Diaspora. In M. L. Broe \& A. Ingram (Eds.), Women's writing in exile. Chapel Hill, NC: University of North Carolina Press.

Fullagar, S. (2001). Encountering otherness: Embodied affect in Alphonso Lingis' travel writing. Tourist Studies, 1(2), 171-183.

Fullagar, S., Markwell, K., \& Wilson, E. (Eds.). (2012). Slow tourism: Experiences and mobilities. Bristol, UK: Channel View Publications.

Gelman, R. G. (2007). Tales of a female nomad: Living at large in the world. New York, NY: Three Rivers Press.

Gilbert, D., \& Abdullah, J. (2004). Holidaytaking and the sense of well-being. Annals of Tourism Research, 31(1), 103-121. doi:10.1016/j.annals.2003.06.001

Goodnow, J., \& Ruddell, E. (2009). An Illustration of the quest genre as spiritual metaphor in adventure travel narratives. Leisure/Loisir, 33(1), 241-268. doi:10.1080/ 14927713.2009.9651438

Hammond, W. F. (2005). Growing and deepening the solo with a creative-reflective journal. In C. E. Knapp \& T. E. Smith (Eds.), Exploring the power of solo, silence, and 
solitude (pp. 49-60). Bolder, CO: Association for Experiential Education.

Hirschorn, S., \& Hefferon, K. (2013). Leaving it all behind to travel: Venturing uncertainty as a means to personal growth and authenticity. Journal of Humanistic Psychology, 53(3), 283-306. doi:10.1177/0022167813483007

Hollander, P. (2007, winter). Traveling in the Peloponnesos. Modern Age, 44-51.

Hooper, G., \& Youngs, T. (2004). Introduction. In G. Hooper \& T. Youngs (Ed.), Perspectives on travel writing (pp 1-12). Aldershot, UK: Ashgate Publishing Limited.

Horn, M. (2010). Leger limini: Wanderers vs. pilgrims in the liminal. The Dulia et Latria Journal, 3, 77-116.

Hottola, P. (2004). Culture confusion: Intercultural adaptation in tourism. Annals of Tourism Research, 31(2), 447-466. doi:10.1016/j.annals.2004.01.003

Johnson, A. A. (2007). Authenticity, tourism, and selfdiscovery in Thailand: Self-creation and the discerning gaze of trekkers and old hands. Journal of Social Issues in Southeast Asia, 22(2), 153-178. doi:10.1355/sj22-2a

Knapp, C. E., \& Smith, T. E. (Eds.). (2005). Exploring the power of solo, silence, and solitude. Boulder, Colorado: Association for Experiential Education.

Knudsen, G. (1997, fall/winter). Travel as pilgrimage in late adulthood. Ageing International, 94-111. doi:10.1007/ s12126-998-1008-7

Krippendorff, K. (2004). Content analysis: An introduction to its methodology (2nd ed.). Beverly Hills, CA: Sage Publications.

Krippendorff, K. (2013). Content analysis: An introduction to its methodology (3rd ed.) Beverly Hills, CA: Sage Publications.

Laing, J., \& Crouch, G. (2011). Frontier tourism: Retracing mythic journeys. Annals of Tourism Research, 38(4), 1516-1534. doi:10.1016/j.annals.2011.02.003

Lett, J. W. (1983). Ludic and liminoid aspects of charter yacht tourism in the Caribbean. Annals of Tourism Research, 10, 35-56. doi:10.1016/0160-7383(83)90114-7

Levitt, H., Frankel, Z., Hiestand, K., Ware, K., Bretz, K., Kelly, R., . . . \& Raina, K. (2004). The transformational experience of insight: A life changing event. Journal of Constructivist Psychology, 17, 1-26. doi:10.1080/107 20530490250660

Lombard, M., Snyder-Duch, J., \& Bracken, C. C. (2002). Content analysis in mass communication assessment and reporting of intercoder reliability. Human Сommunication Research, 28(4), 587-604.

McAvoy, L. H., \& Dustin, D. L. (1989). Resurrecting the frontier. Trends, 26(3), 40-42.

McCabe, S., \& Stokoe, E. H. (2004). Place and identity in tourists' accounts. Annals of Tourism Research, 3(3), 601-622. doi:10.1016/j.annals.2004.01.005

Miller, W. R., \& Bacca, J. (2001). Quantum change: When epiphanies and sudden insight transform ordinary lives. New York, NY: The Gilford Press.

Moir-Bussy, A. (2003). Travel that leads to wisdom. International Journal for the Advancement of Counseling, 21(1), $5-9$.
Noy, C. (2004). Performing identity: Touristic narrative of self-change. Text and Performance Quarterly, 24(2), 115-138. doi:10.1080/1046293042000288353

Obenour, W. L. (2004). Understanding the meaning of 'journey' to budget travelers. International Journal of Tourism Research, 6, 1-15. doi:10.1002/jtr.466

Rantala, O., Rokenes, A., \& Valkonen, J. (2016). Is adventure tourism a coherent concept? A review of research approaches on adventure tourism, Annals of Leisure Research, 1-14. doi:10.1080/11745398.2016.1250647

Reisinger, Y. (2013). Connection between travel, tourism, and transformation. In Y. Reisinger (Ed.), Transformational tourism: Tourist perspectives (pp. 27-32). Oxfordshire, UK: CABI.

Ross, S. L. (2010). Transformative travel: An enjoyable way to foster radical change. Revision, 32(1), 54-61. doi:10.4298/revn.32.1.54-62

Rudwick, M. (1996). Geological travel and theoretical innovation: The role of the 'liminal' experience. Social Studies of Science, 26(1), 143-159.

Russell, R. (2005). Pastimes: The context of contemporary leisure (3rd ed.). Urbana, IL: Sagamore.

Schooler, J. W., \& Melcher, J. (1995). The ineffability of insight. In S. M. Smith, T. B. Ward, \& R. A. Finke (Eds.), The creative cognition approach (pp. 97-134). Cambridge, MA: MIT Press.

Shaffer, T. S. (2004). Performing backpacking: Constructing "authenticity" every step of the way. Text and Performance Quarterly, 24(2), 139-160. doi:10.1080/ 1046293042000288362

Smith, S. M., Ward, T. B., \& Finke, R. (1995). Introduction: Cognitive processes in creative context. In S.M. Smith, T. B. Ward, \& R. A. Finke (Eds.), The creative cognition approach (pp. 1-8). Cambridge, MA: MIT Press.

Sorensen, A. (2003). Backpacker ethnography. Annals of Tourism Research, 20(4), 847-867. doi:10.1016/s01607383(03) 00063-X

Swarbrooke, J., Beard, C., Leckie, S., \& Pomfret, G. (2003). Introductions, definitions, and typologies. In J. Swarbrooke, C. Beard, S. Leckie, \& G. Pomfret (Eds.), Adventure tourism: The new frontier (pp. 3-37). Oxford, UK: Elsevier Ltd.

Thursby, J. S. (2005). American travel literature in the classroom: Inward and outward journeys. In E. Groom (Ed.), Methods for teaching travel literature and writing: Exploring the world of self (pp. 31-42). New York, NY: Peter Lang.

Turner, V. (1966). The ritual process: Structure and antistructure. New York, NY: Cornell University Press.

Van Gennep, A. (1960). The rites of passage. (M. B. Vizedom \& G. L. Cafee, Trans.). London, UK: Routledge.

Varley, P., \& Semple, T. (2015). Nordic slow adventure: Explorations in time and nature. Scandinavian Journal of Hospitality and Tourism, 15(1-2), 73-90. doi:L10. 1080/15022250.2015.1028142.

Von Eye, A., \& Mun, E. (2013). Log-linear modeling: Concepts, interpretation, and application. Hoboken, NJ: Wiley. 
Walle, A. H. (1997). Pursuing risk or insight: Marketing adventures. Annals of Tourism Research, 24(2), 265282. doi:10.1016/s0160-7383(97)80001-1

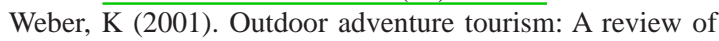
research approaches. Annals of Tourism Research, 28(2), 360-377.

White, N. R., \& White, P. B. (2004). Travel as transition: Identity and place. Annals of Tourism Research, 31(1), 200-218.

Wilson, E., \& Harris, C. (2006). Meaningful travel: Women, independent travel and the search for self and meaning. Tourism, 54(2), 161-172.
Wilson, J., \& Richards, G. (2004). Backpacker icons: Influential literary 'nomad' in the formation of backpacker identities. In G. Richards \& J. Wilson (Eds.), The global nomad: Backpacker travel in theory and practice (pp. 123-148). Clevedon, UK: Channel View Publications.

World Tourism Organization. (2014). UNWTO Global report on adventure tourism. Retrieved from http://www.adven turetravel.biz/store/unwto-global-report-on-adventuretourism/ 